THE article referred to above also records a speech by Prof. M. Saha of the University of Allahabad, who is closely associated with Prof. Mitra in his efforts to obtain more support for research on radio problems. Prof. Saha complains, however, that the apathetic attitude of the authorities towards scientific research is not confined to radio matters. Many research chemists and physicists in India have to carry out their research while working in ill-equipped laboratories under various difficulties arising from insufficient financial provision. In these circumstances, it is certainly very creditable that some of these workers have been able to achieve international renown, but it is highly probable that a little more encouragement on the financial side would be amply repaid in the increase in knowledge and its resulting benefits both to India and the world at large.

\section{Problems of Industrial Recruitment}

Some account of discussions between the Minister of Labour and his predecessor in office and representatives of employers' organizations and the Trades Union Congress General Council on conditions of employment and hours of work in particular industries with reference to unemployment from January 1935 onwards is given in a paper presented to Parliament (Cmd. 5317. London: H.M. Stationery Office. 2d.). In the earlier discussions, the Minister directed special attention to the possibility of increasing the number employed by reducing the hours of work, limitation of overtime, rotation of shifts, regular holidays and the effects of such measures on wages and costs. Difficulties in filling vacancies, the actual or potential shortage of trained work-people and the determination of the effective labour supply among the unemployed nominally attached to various industries were also suggested for investigation, and in later discussions the Minister directed special attention to the need for ascertaining accurately the size and nature of labour supply and unemployment in particular industries, as well as in regard to recruitment, training and hours of work.

REPRESENTATIVES of several industries undertook to supplement the available information in such matters, but the Minister directed attention to the lack of balance in the age distribution or in the labour supply or rate of recruitment which exists between different branches of industry. Evidence of present or prospective shortage of skilled labour in some industries was also discussed, including its bearing on the absorption of other workers in the $\operatorname{sam} \theta$ or in ancillary industries, and the attention of industries was directed to the necessity of considering the new circumstances which would result from the raising of the school-leaving age and the reduction in the number of juveniles who would be available for employment. The discussions have made available a valuable amount of industrial information which should afford a basis for Government or other action if the industries concerned prove unmindful of the responsibilities in regard to the absorption of the unemployed which have thus been brought into prominence, and they illustrate in a striking manner the need for some attempt to handle industrial recruitment on quantitative lines.

\section{The International Commission of Snow}

A NEW section of the Association of Scientific Hydrology to deal with the varied problems of snow and ice was organized in time to hold its first meeting in Edinburgh last September a few days before the official opening of the International Congress of Geodesy and Geophysics. A very large number of papers from all over the world were on the programme, and it was felt that the manifold activities of this new Commission will go far to remove the reproach that the study of snowfall, unlike that of glaciation, has been neglected in most countries, even in those which have much snow. The president, Prof. J. E. Church (U.S.A.), who was unfortunately not able to reach Edinburgh in time for the Conference, being detained in Moscow by illness, presented a valuable address on "Snow Surveying : its Methods and Principles", in which he showed the economic importance of the snowfall in the high mountain ranges of the western United States to the semi-arid plains below. The papers will all eventually appear in the Proceedings of the Association of Scientific Hydrology. The next meeting of the International Snow Commission will be in Washington, D.C., in 1939. Meanwhile, the various national sections will carry out group work in the problems of snow. In view of the first meeting of the Intermational Snow Commission being held in the Scottish capital, the question of British co-operation in the work naturally came into prominence. A British group of members under the chairmanship of Mr. G. Seligman was formed during the early part of 1936, and by the time of the Edinburgh Conference totalled sixteen, of whom ten attended the Conference. Four papers were presented by the British group, two of which, appropriately to the occasion, dealt with snowfall in the British Isles, one by Captain W. N. McClean on the influence of snow and ice on river discharge in the Scottish Highlands, and the other by Mr. L. C. W. Bonacina on problems of drifting snow in moun. tainous districts with special reference to the Scottish Highlands.

\section{Index of Geographical Literature}

Is 1918, the Royal Geographical Society found it necessary on the grounds of economy to abandon the practice hitherto followed of including in each issue of the Geographical Journal a list of additions to the library. These lists from then onwards have been published as separate pamphlets from time to time and distributed to such fellows as expressed a desire to receive them. Up to December 1932, fortyone of these supplements had been published. The entries in these supplements, especially as regards books, atlases and papers, though nominally additions to the catalogues of the Society, in effect comprise a fairly exhaustive list of all geographical literature outside the pages of the Geographical Journal. The Society has now published an "Index to Supplements 